\title{
Developing of X65 steel coils making at Steckel mill using thermo-mechanical control process
}

\author{
Oleksandr Kurpe ${ }^{1}$,Volodymyr Kukhar ${ }^{1, *}$, Eduard $\mathrm{Klimov}^{2}$, Serhii Chernenko², and Andrii Prysiazhnyi ${ }^{1}$ \\ ${ }^{1}$ Pryazovskyi State Technical University, 7 Universytetska Str., Mariupol, 87555, Ukraine \\ ${ }^{2}$ Kremenchuk Mykhailo Ostrohradskyi National University, 20 Pershotravneva Str., Kremenchuk, 39600, Ukraine
}

\begin{abstract}
The process of thermo-mechanically controlled rolling in the conditions of Steckel mill of Ferriera Valsider plant was developed for the first time for hot-rolled coils in the sizes of $12 \mathrm{~mm} \times 1510 \mathrm{~mm}$ from steel of X65 grade for further production of electric welded pipes according to the API-5L standard. The developed process provides carrying out of the roughing-rolling in two stages to facilitating the forming of a smaller austenite grain and therefore more dispersed and homogeneous inherited ferrite structure in the finished rolled product. At the implementation of the process, the holddown of the temperature at the desired level at 1780 Steckel rolling mill has been carried out by adjusting the number of burners in furnace coilers. The process of controlled air cooling of rolled coils to a temperature of $400{ }^{\circ} \mathrm{C}$ after winding in the developed technology for Steckel's mill condition of Ferriera Valsider plant is applied for the first time that allowed to reduce the thickness of the air scale layer and to improve the surface quality. The performed research has been allowed to evaluate the feasibility of the operating equipment and to determine the possibility of coils fabrication related to the nowadays world requirements and satisfied to the demand of European electricwelded pipes manufacturers.
\end{abstract}

\section{Introduction}

Ferrous metallurgy, and hot rolling in particular, is one of the most energy-consuming industries. The improvement of metallurgical technologies is referred to a modern urgently needed global trends aimed to the reducing of carbon dioxide emissions, decreasing the impact on climate change, creating the new environmentally friendly metal materials that reduce a material consumption and increase the safety of vehicles, engineering structures, pipelines and other specific infrastructure.

The most common method of making flat rolled products for large diameter pipes is rolling on plate reversible mills $[1,2]$, as well as on continuous rolling mills $[3,4]$. A special place is occupied by the production of plate steel for pipe assortment at Steckel rolling mills. This method is less common, but is successfully used by global manufacturers. There is no analogue of the production implementation of largediameter pipe assortment at the Steckel rolling mills in the territory of post-Soviet space. At the same time in Canada, the USA, South Korea, China, this method of production is common $[5,6]$.

Obtaining the required properties of the rolled steel in all cases is achieved mainly by the thermo-mechanical processing with or without of the accelerated cooling. The progressiveness of Steckel mills use lies in the significant manufacture greening through the use of heat-preserving and insulating furnace coilers, which help to reduce of the energy costs, make less the scale formation and $\mathrm{CO}_{2}$ emissions. There are three general approaches to rolling product making that are used as inputs to the pipemaking process [7-12]: normalizing, thermomechanical controlled processing (TMCP), and quenching and tempering (Q\&T). The combination of rolling processes in Steckel mills with TMCP has significant prospects at the point of view of obtaining steels of high and ultra-high strength grades, raising the standards of human safety.

The use for the manufacture of large-diameter pipes of plate or coiled steel, and hence their manufacture as longitudinal or spiral seam ones, depends largely on the political and historically formed technical and technological aspects of a particular region. While in large-scale projects in Eastern European and Asian countries are predominate longitudinal seam pipelines, in a number of European countries, as well as in Canada and the USA, spiral seam pipes are widely used [13, 14]. There are steels from X42 to X120 according to API standard using [15]. Undoubtedly, the advantages and disadvantages are available for both manufacturing options, from sheet metal products and pipes, and ending with the direct operation of pipelines.

In recent years, the process of manufacturing of hot rolled products on Steckel rolling mills has developed. The hot-rolled strength steel was the basic assortment made on such mills, producing at which is necessary to maintain temperature of metal in austenitic area. Modern Steckel mills and processes allow to produce

\footnotetext{
*Corresponding author:kvv.mariupol@gmail.com
} 
rolled products with controlling the temperature level to obtain the desired set of mechanical properties of the finished rolled product [16-19]. Functioning mills by their design are divided into several types: single-stand, double-stand, roughing rolling stand, with additional finishing stands $[16,19]$.

The processes of Steckel mill rolling high-strength steels, intended mainly for the production of large pipe, were investigated in papers [20-23]. The processes proposed by the authors of works [20,21, 24], related to the production of rolled products for large diameter pipes of steel grade X80, are of practical importance. It should be noted that these technologies are implemented on the equipment created in the 1990's, which allows to conduct a particular analysis of technical capabilities and differences of equipment built earlier. In paper [22], the authors present a study of the influence of temperature on the formation of structural components along the strip in the production of austenitic steels, the results of which can be partially applied in the development of the technology or its adjustment.

In works [25-30] the researches of separate processes which also using on design of a rolling at Steckel mill are presented. At indicated, temperature and strain rate conditions play a significant role in obtaining a high-quality steel structure, mechanical properties and other quality indices [25-30]. So in paper [31], the temperature drop in closed coilers is taken into account, and the theoretical consideration of the indentation of a roller tool into a slab allows one to evaluate deformation and power modes [29, 32-35]. The most important factor is the friction conditions, the forecast of which during hot rolling is carried out according to complex equations that have restrictions on the parameters of the chemical composition of rolled steels [36]. Also, the results of a study on laboratory modeling of Steckel mill rolling, which are presented in work [37] are of a particular interest. The above approaches are associated with a number of assumptions that reduce the accuracy of preventive technological solutions. Therefore, conducting research in an industrial environment at Steckel mill is a more accurate, albeit more expensive, method.

It should be noted that a limited number of studies leave open the question of assessing the technical capabilities of the existing equipment of Steckel rolling mills relate to developing a new assortment of high grade categories. From year to year, the level of customer requirements for pipe steel increases significantly and sometimes exceeds the level of requirements of standards that are regularly reviewed. A significant toughening of requirements also has applied to API 5L X65 steel [38-41], compared to the years of commissioning of the Steckel mill (in case of Ferriera Valsider plant). Hence, designing the production technology of rolled steel for pipes on the Steckel mills of Ferriera Valsider plant of steel grade X65 is an urgent task that will assess the technical capabilities of the existing equipment and establish the possibility of producing coils that meet nowadays world requirements and meet the needs of European manufacturers of electric-welded pipes.
Purpose of the research. The purpose of the work is to develop the production technology of the assortment of hot-rolled coils of steel grade X65 at the Steckel rolling mill of the Ferriera Valsider plant (Italy), taking into account the technical features of the existing heating and rolling equipment.

\section{Materials and strategy of research}

The main equipment of the Steckel rolling mill line of the Ferriera Valsider SpA plant is a methodical pusher furnace with six zones for heating slabs, manufactured by Bendotti company, which is heated by natural gas with a capacity of $120 \mathrm{t} / \mathrm{h}$, mill 3170 for rolling slabs and strip plates for the Steckel rolling mill, which includes reverse duo stand with a rolling force of up to $25 \mathrm{MN}$, and a stand with vertical rolls, a seven-zone roller furnace for intermediate heating of the strip plate, which is heated by natural gas. The Steckel rolling mill includes a reversible quarto stand 1780 with a rolling force of up to $24 \mathrm{MN}$ and a chamber furnace with natural gas-heated drum coilers located on both sides of the rolling mill 1780. Unit for laminar cooling of the strip after rolling with a length of $41 \mathrm{~m}$, which allows to cool the metal at a speed of up to $40{ }^{\circ} \mathrm{C} / \mathrm{s}$. Winders for coiling the strip up to $20 \mathrm{~mm}$ thick.

The main assortment of the rolling mill is heavy plate and coiled rolled products for construction purposes, including resistant to atmospheric corrosion, rolled products for shipbuilding and production of parts for mechanical engineering. The assortment produced is determined by the existing technological regulations of the operation of all main equipment, i.e. high heating temperatures of slabs for rolling, about $1230^{\circ} \mathrm{C}$, high temperature of the furnace with intermediate heating of the rolling from $1100^{\circ} \mathrm{C}$ to $1250{ }^{\circ} \mathrm{C}$, high temperatures of furnace coilers about $1070^{\circ} \mathrm{C}$. It should be noted that at these temperatures there is a significant reserve of energy-power parameters. The actual rolling force in roughing and finishing stands is in the range of 12-14 $\mathrm{MN}$, with a relative reduction per a pass from $15 \%$ to $50 \%$ according to the assortment, which makes possible further development of technology and expansion of the assortment. The scheme of the main technological line for the production of hot-rolled coils at the Ferriera Valsider plant is shown in Fig. 1.

In Fig. 2 the finishing stand of the Steckel mill 1780/quarto with furnace coilers and in Fig. 3 is the laminar cooling system are shows. The assessment of the plant capacity to master the technology of production of coils of pipe assortment was based on the analysis of the technical characteristics of the existing equipment.

As a result of the analysis and preliminary calculations of maximum allowable technological loads on the main equipment of the stands, with the help of mathematical modeling complex insufficient power of the main drive engines of the 3170 mill and 1780 Steckel rolling mill at quite high power characteristics of both stands, which does not allow to operate them at full 
power. Based on the calculation, the following results were obtained, Table 1.

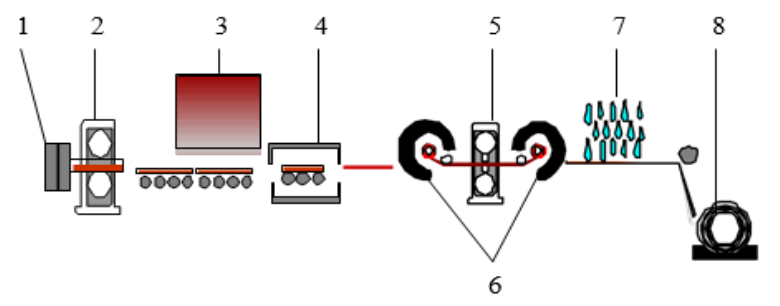

Fig. 1. The scheme of the technological line for the production of hot-rolled coils at the Ferriera Valsider plant: 1 - stand with vertical rolls; $2-$ roughing stand 3170; 3 - continuous pusher furnace; 4 - continuous roller furnace; 5 - Steckel stand 1780; 6 - furnace coiler; 7 - laminar cooling; 8 - coiler.

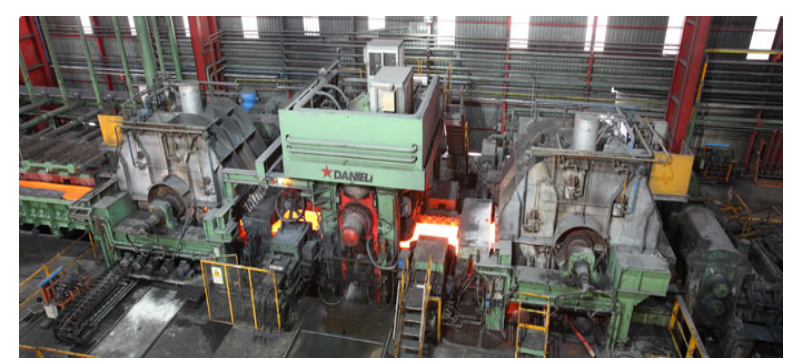

Fig. 2. Finishing stand of the Steckel mill 1780/quarto with furnace coilers.

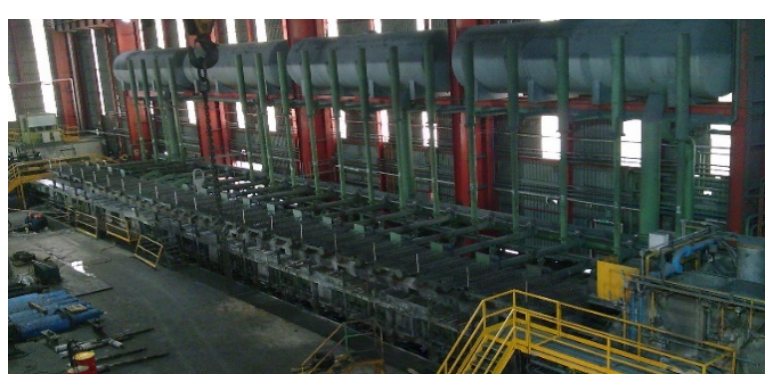

Fig. 3. Laminar cooling system.

Table 1. Comparison of actual and calculated engine power.

\begin{tabular}{|c|c|c|c|c|}
\hline Stand/type & $\begin{array}{c}\text { Number } \\
\text { of main } \\
\text { drive } \\
\text { engines }\end{array}$ & $\begin{array}{c}\text { Maximum } \\
\text { rolling } \\
\text { force, } \mathbf{M N}\end{array}$ & $\begin{array}{c}\text { Actual } \\
\text { engine } \\
\text { power, } \\
\text { kW }\end{array}$ & $\begin{array}{c}\text { Calculated, } \\
\text { required } \\
\text { engine } \\
\text { power, } \mathbf{k W}\end{array}$ \\
\hline $3170 /$ duo & 2 & 25 & $2 \times 2240$ & $2 \times 4430$ \\
\hline 1780 quarto & 2 & 24 & $2 \times 4480$ & $2 \times 5770$ \\
\hline
\end{tabular}

Thus, improving the efficiency of the mills at the Ferriera Valsider plant by increasing productivity, reducing specific energy consumption, improving the quality of products is possible by installing new, more powerful main drive engines. Insufficient engine power makes difficulties in the development and implementation of thermo-mechanical rolling technology on the existing equipment.

Development of the production technology of the pipe assortment coils is possible in two following options. Implementation on the rolling mill of TMCP technology without accelerated cooling with the need to complete the deformation in the ferritic range, which will lead to a significant (up to $30 \%$ ) loss of productivity due to the forced increase in the number of passes. In addition, when performing finishing rolling it will be quite difficult to plan and implement the operation of the furnace coilers as part of the power characteristics during coiling, and directly maintain the required temperature of rolling, which will vary widely. The use of TMCP technology with accelerated cooling is a more acceptable option. The undoubted advantage of this technology is the higher consumer properties of the products, which has been repeatedly emphasized by many studies, lower production costs, including by reducing the level of microalloying elements added to the steel, reducing energy consumption for heating and rolling. In addition, and what is especially important for this Steckel rolling mill, is the reduction of loads on the engines of the main drive and furnace coilers due to the deformation in a higher temperature range.

\section{Results and Process Developing}

As a billet for the production of coils with dimensions $12 \mathrm{~mm} \times 1510 \mathrm{~mm}$, steel grade X65 was considered the use of slabs of "AZOVSTAL IRON AND STEEL WORKS" current production, cross section $220 \mathrm{~mm}$ x $1510 \mathrm{~mm}$. The chemical composition of the experimental slabs are given in Table 2 . Slabs are heated in a six-zone methodical furnace. The heating temperature of slabs for rolling should be $1170^{\circ} \mathrm{C} \pm 10^{\circ} \mathrm{C}$. Determination of the required austenitization temperature was carried out on the basis of data on the solubility temperatures of $\mathrm{NbC}$ and $\mathrm{Nb}$ particles $(\mathrm{C}, \mathrm{N})$ in the structure of a uninterruptedlycasted slab. The heated slabs enter the roughing stand of the duo mill 3170 , preliminary passing the water wash box to remove furnace scale from the surface. The temperature of the slabs after the water wash should be $1130{ }^{\circ} \mathrm{C} \pm 10^{\circ} \mathrm{C}$.

Rolling in a rough stand should be carried out according to the longitudinal scheme in two stages. The first stage of the rolling is carried out in the upper part of the austenitic area in the temperature range from 1130 ${ }^{\circ} \mathrm{C}$ to $1020^{\circ} \mathrm{C}$, where intensive recrystallization of the deformed austenite takes place, with a reduction of more than $10 \%$ per a pass, except for the first two or three passes, in which the reduction is limited by the maximum angle of capture, power and engine torque. After performing the first stage, the roll is cooled by translational movement on the roller conveyor to a temperature of $920^{\circ} \mathrm{C}$. The absence of deformation in this temperature range allows to keep part of the niobium in dissolved form for further dispersion hardening of the metal, as at this stage incoherent particles $\mathrm{Nb}(\mathrm{C}, \mathrm{N})$, as well as $\mathrm{Ti}(\mathrm{C}, \mathrm{N})$ separated, do not make significant changes in steel hardening. The last 2-4 passes are performed in the area of recrystallization inhibition in the temperature range of $920-880^{\circ} \mathrm{C}$, with a reduction $\geq 10 \%$.

Implementation of rough rolling in two stages promotes the formation of smaller austenitic grains, and more dispersed and homogeneous inherited ferrite 
structure in the finished rolled products. The thickness of the rolling should be not less than three times the final thickness. The recommended temperature-deformation modes of rolling through the passes in the stand 3170 are given in Table 3.

After rolling in a roughing stand, a $40 \mathrm{~mm}$ thick rolling is cooled on a roller conveyor to a temperature of $830-820{ }^{\circ} \mathrm{C}$. Then the rolling goes to the continuous rolling furnace, where the temperature is equalized in cross section and length, as well as the side edges are heated. The temperature of the metal after equating in the rolling furnace should be $835^{\circ} \mathrm{C} \pm 5^{\circ} \mathrm{C}$.
The final rolling is carried out in the stand of the quarto Steckel rolling mill. Rolling in the Steckel stand should begin at a temperature of $825-835^{\circ} \mathrm{C}$, i.e. below the temperature of complete inhibition of austenite recrystallization, and end at a temperature of not less than $810^{\circ} \mathrm{C}$. The reduction on all passes must be at least $10 \%$. During the implementation of the described temperature-strain parameters during finishing rolling, austenitic grains are extracted, the boundaries of which are fixed by $\mathrm{Nb}(\mathrm{C}, \mathrm{N})$ phases released during rolling and will significantly grind the inherited ferrite grain. The recommended temperature-deformation mode of rolling on passes in a stand 1780 is given in Table 4.

Table 2. The chemical composition of the experimental steel grade X65.

\begin{tabular}{|c|c|c|c|c|c|c|c|c|c|c|c|c|c|c|c|c|}
\hline \multirow{2}{*}{$\begin{array}{c}\text { Melt } \\
\text { number }\end{array}$} & \multirow{2}{*}{$\begin{array}{l}\text { Section of } \\
\text { slabs, } \mathrm{mm}\end{array}$} & \multicolumn{15}{|c|}{ Chemical composition, $\%$} \\
\hline & & $\mathbf{C}$ & Mn & Si & $\mathbf{S}$ & $\mathbf{P}$ & $\mathbf{A l}$ & $\mathbf{N b}$ & $\mathbf{V}$ & $\mathbf{C u}$ & $\mathbf{N i}$ & $\mathbf{C r}$ & Mo & $\mathbf{T i}$ & $\mathbf{N}$ & $\mathbf{B}$ \\
\hline 1002129 & $220 \times 1510$ & 0.09 & 1.40 & 0.23 & 0.002 & 0.011 & 0.036 & 0.030 & 0.066 & 0.02 & 0.02 & 0.03 & 0.01 & 0.015 & 0.0070 & 0.0005 \\
\hline
\end{tabular}

Table 3. Recommended temperature-deformation schedule of rolling in the roughing stand 3170.

\begin{tabular}{|c|c|c|c|c|c|}
\hline $\begin{array}{c}\text { Number of } \\
\text { the pass }\end{array}$ & $\begin{array}{c}\text { Thickness before } \\
\text { the pass, } \mathbf{~ m m}\end{array}$ & $\begin{array}{c}\text { Thickness after the } \\
\text { pass, } \mathbf{~ m m}\end{array}$ & Reduction, $\%$ & $\begin{array}{c}\text { Temperature before } \\
\text { the pass, }{ }^{\circ} \mathbf{C}\end{array}$ & Rolling force, MN \\
\hline 1 & 222 & 202 & 9.0 & 1130 & 14.07 \\
\hline 2 & 202 & 183 & 9.4 & 1122 & 14.22 \\
\hline 3 & 183 & 165 & 9.8 & 1117 & 14.25 \\
\hline 4 & 165 & 148 & 10.3 & 1113 & 14.24 \\
\hline 5 & 148 & 132 & 10.8 & 1107 & 14.28 \\
\hline 6 & 132 & 117 & 11.4 & 1102 & 14.38 \\
\hline 7 & 117 & 103 & 12.0 & 1094 & 14.43 \\
\hline 8 & 103 & 90 & 12.6 & 1087 & 14.26 \\
\hline 9 & 90 & 78 & 13.3 & 1076 & 14.46 \\
\hline 10 & 78 & 67.5 & 13.5 & 1066 & 14.54 \\
\hline 11 & 67.5 & 58 & 14.1 & 1051 & 14.42 \\
\hline 12 & 58 & 49.5 & 14.7 & 917 & 14.40 \\
\hline \multicolumn{7}{|l|}{ Cooling on a roller conveyor } \\
\hline 13 & 49.5 & 44.5 & 10.1 & 902 & \\
\hline 14 & 44.5 & 40 & 10.1 & & \\
\hline
\end{tabular}

Table 4. Recommended rolling schedule in the stand 1780 of the Steckel rolling mill.

\begin{tabular}{|c|c|c|c|c|c|}
\hline $\begin{array}{c}\text { Number of } \\
\text { the pass }\end{array}$ & $\begin{array}{c}\text { Thickness before } \\
\text { the pass, mm }\end{array}$ & $\begin{array}{c}\text { Thickness after the } \\
\text { pass, mm }\end{array}$ & Reduction, $\%$ & $\begin{array}{c}\text { Temperature before } \\
\text { the pass, }{ }^{\circ} \mathbf{C}\end{array}$ & Rolling force, MN \\
\hline 1 & 40 & 35.5 & 11.25 & 830 & 14.60 \\
\hline 2 & 35.5 & 31.5 & 11.27 & 829 & 13.97 \\
\hline 3 & 31.5 & 28 & 11.11 & 828 & 13.22 \\
\hline 4 & 28 & 24.5 & 12.50 & 827 & 13.75 \\
\hline 5 & 24.5 & 21.5 & 12.24 & 826 & 12.89 \\
\hline 6 & 21.5 & 18.5 & 13.95 & 825 & 13.50 \\
\hline 7 & 18.5 & 16 & 13.51 & 824 & 12.49 \\
\hline 8 & 16 & 14 & 12.50 & 822 & 11.23 \\
\hline 9 & 14 & 12 & 14.29 & 819 & 1.87 \\
\hline
\end{tabular}

The schedule of reductions is calculated so that the last pass is performed during the rolling process.

Changes in temperature and rolling force in the passes in the Steckel stand are shown in Fig. 4. In order to meet the conditions of the thermomechanical rolling process, it is necessary to maintain the temperature of the metal in the passes in the Steckel stand. When modeling the technology of maintaining the temperature at the desired level, which is low with relation to the current technology, is carried out by adjusting the number of burners in the furnace coilers.

After rolling, the strip is transferred without delay to the laminar cooling unit. The sequence of going through the technological units before laminar cooling should be as follows: (i) Furnace coiler before the mill $\rightarrow$ (ii) Steckel rolling mill $\rightarrow$ (iii) Laminar cooling. Due to the short distance of the rolling fields, the work of all technological equipment must be synchronized. Cooling of the coils on the accelerated cooling unit should be 
performed at a speed of $12-14^{\circ} \mathrm{C} / \mathrm{s}$ to a temperature of $560-580{ }^{\circ} \mathrm{C}$.

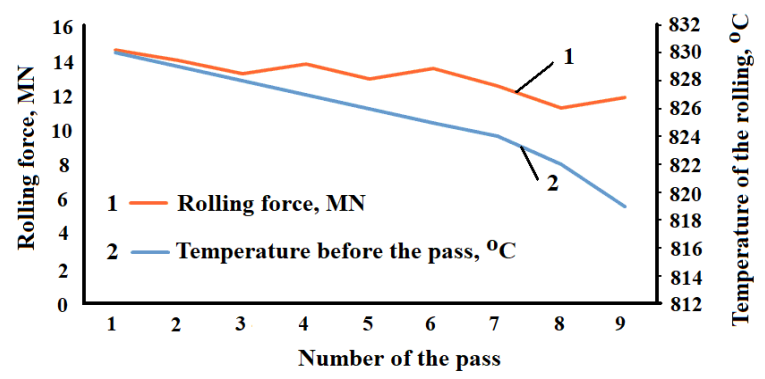

Fig. 4. Dynamics of changes in rolling force (1) and temperature (2) in the passes in the Steckel stand.

The accelerated cooling from the lower range of the austenitic area will form the final dispersed ferritobainite structure in the finished product. At this stage the separation of $\mathrm{Nb}(\mathrm{C}, \mathrm{N})$ particles from the solid solution will significantly increase the strength of the metal. After the accelerated cooling, the strip is rolled into a coil on the finishing coiler. In order to reduce the thickness of the air scale, the rolled coils must be subjected to additional controlled air cooling to a temperature of $400{ }^{\circ} \mathrm{C}$, using industrial aerators. The final slow cooling of the rolls is performed in the warehouse during 48 hours.

\section{Conclusions}

For the conditions of the Steckel rolling mill of the Ferriera Valsider SpA plant, the assessment of technical capacity and the development of a complex technology were conducted for the first time for the production of coils of steel grade X65 for further production of large diameter electric-welded pipes for oil and gas. The calculations were conducted and the required capacity of the main engines of rolling mills 3170 and 1780 were installed for the first time at the Ferriera Valsider SpA plant, which will increase the productivity, reduce specific energy consumption and improve the quality of produced products. In order to improve the quality of the surface of the coils, the use of controlled air cooling of the coils after coiling was proposed for the first time for Steckel rolling mill.

\section{References}

1. H. Pujiyanto, AIP Conf. Proc. 1805, 060001 (2017). doi:10.1063/1.4974437

2. V.V. Yashin, E.V. Aryshenskii, E.D. Beglov, M.S. Tepterev, A.F. Grechnikova, Key Eng. Mater. 746, $48 \quad$ (2017). doi:10.4028/www.scientific.net/kem.746.48

3. V.V. Shokhin, O.V. Permyakova, Procedia Eng. 129, 231 (2015). doi:10.1016/j.proeng.2015.12.038

4. Y. Licheng, H. Jingxiang, N. Liwei, L. Yingchun, in Proceeding of Asia Simulation Conference - 7th Int. Conference on System Simulation and Scientific
Computing, IEEE, Beijing, China, 2008. doi:10.1109/asc-icsc.2008.4675462

5. S. Francesco, P. Alessandro, Iron Steel 43(6), 93 (2008)

6. K. Berger, J. Frenn, in 53nd Rolling Seminar, vol. 53, Rio de Janeiro, RJ, Brazil, 26-30 September 2016. doi:10.5151/1983-4764-27976

7. W. Almeida, H. Rodrigues, M. Rebellato, F. Bastos, R. Barbosa, in HSLA Steels 2015, Microalloying 2015 \& Offshore Engineering Steels 2015, The Chinese Society for Metals and Chinese Academy of Engineering, The Minerals, Metals \& Materials Society, 2016

8. D. Bai, et al, in Proceeding of AIST 2011 International Symposium on the Recent Developments in Plate Steels, Winter Park, Colorado, USA, June 2011

9. N. Switzner, S. Thorsson, J. Kornuta, P. Veloo, P. Martin, T. Rovella, M. Rosenfeld, in Proceeding of Conference Pipeline Pigging and Integrity Management, Houston, TX, USA, 17-21 February 2020

10. L.S. Malinov, I.E. Malysheva, E.S. Klimov, V.V. Kukhar, E.Yu. Balalayeva, Mater. Sci. Forum 945, 574 (2019). doi:10.4028/www.scientific.net/MSF.945.574

11. A.S. Anishchenko, Metallovedenie i Termicheskaya Obrabotka Metallov 4, 31 (1996)

12. V.G. Efremenko, V.I. Zurnadzhi, Y.G. Chabak, O.V. Tsvetkova, A.V. Dzherenova, Mater. Sci. 53(1), 67 (2017). doi:10.1007/s11003-017-0045-3

13. Welded Steel Pipe. Design Manual. Merits, Design Standards, Technical Data and References (American Iron and Steel Institute, NW, 2007)

14. Y. Yin, Y. Huang, Y. Yao, D. Wang, Y. Wu, D.G. Stalheim, in Proceeding of the 2008 7th International Pipeline Conference, ASME, 29 September - 3 October 2008. Vol. 3 (Calgary, Alberta, Canada, 2008), p. 147. doi:10.1115/IPC2008-64211

15. D.G. Stalheim, K.R. Barnes, D.B. McCutcheon, in Proceeding of International Symposium on Microalloyed Steels for the Oil and Gas Industry, ed. by W.J. Fazackerley, P. Bordignon, K. Hulka, F. Siciliano. The Minerals, Metals \& Materials Society, 2007

16. G. John Lenard, Primer on flat rolling, 2nd edition (Elsevier Ltd, Ontario, Canada, 2014)

17. A. Bohlin, H. Nygren, O. Jepsen et al, MPT International 6, 56 (2002)

18. L. Otavio, D. Berger, G. Djumlija, F. Reiter, A. Marples, K. Berger, Rev. Métall. 102(9), 583 (2005). doi:10.1051/metal:2005175

19. D.G. Stalheim, Ironmaking Steelmaking 36(4), 259 (2009). doi:10.1179/174328109x439252

20. L.E. Collins, F. Hamad, M. Kostic, T. Lawrence, in Proceeding of International Symposium on 
Microalloyed Steels for the Oil and Gas Industry, ed. by W.J. Fazackerley, P. Bordignon, K. Hulka, F. Siciliano. The Minerals, Metals \& Materials Society, 2007

21. L.E. Collins, in Proceeding of the International Symposium Niobium, Orlando, Florida, USA, 2-5 December 2001

22. R.D. Knutsen, S. Parker, ISIJ Int. 48(2), 200 (2008). doi:10.2355/isijinternational.48.200

23. E.A. Goli-Oglu, Yu.D. Morozov, Steel Transl. 43, $520(2013)$

24. W. Ding, Z. Jiang, J. Li, S. Li, C. Zha, X. Bai, Q. Li, G. Zhang, D. Stalheim, in Proceeding of the 2012 9th International Pipeline Conference, ASME, 2428 September 2012. Vol. 3 (Calgary, Alberta, Canada, 2012), p. 285. doi:10.1115/IPC201290326

25. L.B. Godefroid, B.M. Sena, V.B. Trindade Filho, Mat. Res. 20(2), 514 (2017). doi:10.1590/19805373-mr-2016-0545

26. E.N. Smirnov, A.N. Smirnov, V.A. Sklyar, V.A. Belevitin, S.P. Eron'ko, R.E. Pivovarov, Steel Transl. 48(6), $381 \quad$ (2018). doi:10.3103/S0967091218060104

27. G.A. Orlov, V.V. Kotov, A.G. Orlov, Metallurgist 61(1-2), 106 (2017). doi:10.1007/s11015-0170461-5

28. A.S. Anishchenko, Y.V. Feofanov, A.B. Bogun, Khim. Neftegazov. Mashinostr. 11, 33-35 (1992)

29. A. Shapoval, V. Drahobetskyi, I. Savchenko, A. Gurenko, O. Markov, Key Eng. Mater. 864, 285 (2020).

doi:10.4028/www.scientific.net/KEM.864.285
30. T. Tomida, K. Miyata, H. Nishibata, in Nanostructured Metals and Alloys, vol. 24, ed. by Sung H. Whang (Woodhead Publishing, 2011), p. 747. doi:10.1533/9780857091123.4.747

31. V. Kukhar, O. Kurpe, E. Klimov, E. Balalayeva, V. Dragobetskii, Int. J. Eng. Technol. (UAE) 7(4.3), 35 (2018). doi:10.14419/ijet.v7i4.3.19548

32. N.S. Hrudkina, L.I. Aliieva, FME Trans. 48(2), 357 (2020). doi:10.5937/fme2002357H

33. V. Artiukh, V. Kukhar, E. Balalayeva, MATEC Web Conf. 224, $01036 \quad$ (2018). doi:10.1051/matecconf/201822401036

34. Y.K. Oginskyy, Metall. Min. Ind. 2(6), 401 (2010)

35. V. Botnari, S. Mazuru, Appl. Mech. Mater. 657, 147 doi:10.4028/www.scientific.net/AMM.657.147

36. V.I. Kaplanov, A.G. Prisyazhnyi, Steel Transl. 38(9), 714 (2008). doi:10.3103/S0967091208090040

37. J.S. Hinton, J.H. Beynon, Steel Res. Int. 79(4), 277 (2008). doi:10.2374/SRI07SP060-79-2008-278

38. P. Thiangpak, A. Rodchanarowan, Mater. Today: Proc. 5(3), 9393 (2018). doi:10.1016/j.matpr.2017.10.115

39. J. Baek, Y. Kim, C. Kim, W. Kim, C. Seok, Mater. Sci. Eng. A 527(6), 1473 (2010). doi:10.1016/j.msea.2009.10.017

40. S.H. Hashemi, Mater. Sci. Eng. A 528(3), 1648 (2011). doi:10.1016/j.msea.2010.10.089

41. E. El-Danaf, M. Baig, A. Almajid, W. Alshalfan, M. Al-Mojil, S. Al-Shahrani, Mater. Des. 47, 529 (2013). doi:10.1016/j.matdes.2012.12.031 